\title{
PENERAPAN KESELAMATAN PASIEN DI RUANG RAWAT INAP
}

\author{
Elisa Widyawati \\ elisawidyawati10@gmail.com
}

\section{LATAR BELAKANG}

Rumah sakit sebagai organisasi sistem pelayanan kesehatan mempunyai elemen-elemen yang saling interaksi dan interdependesi yang kuat. Keselamatan (safety) telah menjadi isu global untuk rumah sakit. Ada lima isu penting yang terkait dengan keselamatan di rumah sakit yaitu keselamatan pasien (patient safety), keselamatan pekerja atau petugas kesehatan, keselamatan bangunan dan peralatan di rumah sakit yang bisa berdampak terhadap keselamatan pasien dan petugas, keselamatan lingkungan yang berdampak terhadap pencemaran lingkungan dan keselamatan bisnis rumah sakit yang terkait dengan kelangsungan hidup rumah sakit. Keselamatan pasien merupakan sesuatu yang jauh lebih penting dari pada sekedar efisiensi pelayanan, dan perilaku dengan kemampuan perawat sangat berperan penting. Salah satu sasaran keselamatan pasien adalah tercapainya pengurangan resiko infeksi terkait pelayanan kesehatan. Perilaku perawat dengan kemampuan perawat sangat berperan penting dalam pelaksanaan keselamatan pasien. Salah satu tujuan penting dari penerapan sistem keselamatan pasien di rumah sakit adalah mencegah dan mengurangi Insiden Keselamatan Pasien (IKP) adalah suatu kejadian atau situasi yang dapat mengakibatkan atau berpotensi mengakibatkan cidera pada pasien.

Keberhasilan penerapan keselamatan pasien ini menjadi tanggung jawab seluruh komponen dalam rumah sakit termasuk perawat. Perawat merupakan tenaga kesehatan yang selalu mendampingi pasien sehingga sangat berisiko melakukan kelalaian yang dapat menyebabkan pasien cedera bahkan mencapai angka 86\% (Maryam, 2009). Perawat dalam memberikan asuhan keperawatan kepada pasien harus menerapkan keselamatan pasien. Perawat harus melibatkan kognitif, afektif, dan tindakan yang mengutamakan keselamatan pasien. Disisi lain, perawat khususnya perawat pelaksana merupakan garda terdepan dalam menjamin keselamatan pasien terutama pada pasien rawat inap karena perawat pelaksana memiliki 
kuantitas kontak dengan pasien paling banyak dibandingkan tenaga kesehatan yang lain. Oleh karena itu, pengalaman perawat pelaksana dalam menjamin keselamatan pasien dapat menjadi sesuatu yang menarik untuk digali. Ketepatan dalam mengidentifiksi pasien selanjutnya perawat harus melakukan komunikasi yang efektif dengan pasien agar pasien semakin yakin kepada perawat. Untuk meningkatkan keselamatan pasien, perawat harus mencuci tangan (hand hygine) terlebih dahulu sebelum memberikan asuhan keperawatan kepada pasien agar tidak terkena infeksi nosokomial.

\section{METODE}

Penerapan keselamatan pasien di ruang rawat inap digunakan dalam kajian ini yaitu dengaan melakukan analisis data sekunder, yakni teknik pengumpulan data dari berbagai sumber seperti textbook dan jurnal untuk mendapatkan data dan informasi yang lengkap dengan cara menyimpulkan dari 10jurnal dengan tahun paling tua 2012. Dengan mencari dari berbagai jurnal maupun textbook dapat mudah dipahami dan dimengerti serta menyimpulkan nya dengan bahasa sendiri tanpa harus meniru karya orang lain.

\section{HASIL}

World Health Organization (WHO) menyatakan keselamatan pasien merupakan masalah kesehatan masyarakat global yang serius. Kesalahan medis dapat disebabkan oleh faktor sistem dan faktor manusia. Insiden keselamatan pasien yang merugikan adalah terkait dengan prosedur bedah $(27 \%)$, kesalahan pengobatan $(18,3 \%)$ dan kesehatan infeksi terkait perawatan $(12,2 \%)$ (WHO, 2017). Sedangkan di Eropa, kejadian pasien dengan risiko infeksi sebanyak 83,5\% dan bukti kesalahan medis menunjukkan 50- 72,3\%. Berdasarkan hasil penelitian menunjukkan bahwa untuk meningkatkan keselamatan pasien, langkah pertama yang harus dilakuakan oleh perawat ialah ketepatan dalam mengidentifiksi pasien selanjutnya perawat harus melakukan komunikasi yang efektif dengan pasien agar pasien semakin yakin kepada perawat. Untuk meningkatkan keselamatan pasien, perawat harus mencuci tangan (hand hygine) terlebih dahulu sebelum memberikan asuhan keperawatan kepada pasien agar tidak terkena infeksi nosokomial. 
Hasil penenlitian dengan judul "evaluasi pelaksanaan sistem identifikasi pasien di Instalasi Rawat Inap Rumah Sakit” mengemukakan bahwa secara terstruktur identifikasi pasien sudah

cukup lengkap. Pengetahuan perawat tentang sistem identifikasi sudah cukup baik. Komunikasi yang baik dan benar perlu dilakukan untuk mengkoordinasikan asuhan keperawatan yang melibatkan banyak profesi selain profesi perawat. Komuniasi dalam praktek keperawatan merupakan elemen penting bagi perawat dalam melaksanakan asuhan keperawatan untuk mendapatkan hasil yang optimal

Penerapan keselamatan pasien dilaksanakan dengan baik maka pelayanan yang mengutamakan keselamatan dan kualitas yang optimal akan memberikan dampak yang luas. Terutama bagi masyarakat akan mendapatkan pelayanan yang lebih berkualitas, aman dan memenuhi harapan mereka. Bagi rumah sakit menjadi nilai tambah untuk pencapaian pelayanan yang berstandar nasional dan internasional. Dalam sistem akreditasi KARS 2012, mengarahkan seluruh kegiatan pelayanan rumah sakit agar mampu memberikan pelayanan yang memenuhi standar kualitas serta jaminan rasa aman dan perlindungan terhadap dampak pelayanan yang diberikan dalam rangka pemenuhan hak-hak. Rumah sakit merupakan salah satu tempat yang paling mungkin rentan mendapat infeksi karena mengandung populasi mikroorganisme yang sangat tinggi dengan jenis virus yang mungkin resisten terhadap antibiotik (Potter \& Perry, 2005).

\section{PEMBAHASAN}

Rumah Sakit (RS) adalah institusi pelayanan kesehatan bagi masyarakat dengan karateristik tersendiri yang dipengaruhi oleh perkembangan ilmu pengetahuan kesehatan, kemajuan teknologi, dan kehidupan sosial ekonomi masyarakat yang harus tetap mampu meningkatkan pelayanan yang lebih bermutu dan terjangkau oleh masyarakat agar terwujud derajat kesehatan yang setinggi-tingginya,

Keselamatan merupakan kebutuhan dasar manusia. Keselamatan juga merupakan hal yang sangat penting dalam setiap pelayanan kesehatan, sehingga dapat dikatakan bahwa keselamatan merupakan tanggung jawab dari pemberi jasa pelayanan kesehatan. Keselamatan (safety) telah menjadi isu global untuk rumah sakit. Ada lima isu penting yang terkait dengan keselamatan di 
rumah sakit yaitu keselamatan pasien (patient safety), keselamatan pekerja atau petugas kesehatan, keselamatan bangunan dan peralatan di rumah sakit yang bisa berdampak terhadap keselamatan pasien dan petugas, keselamatan lingkungan yang berdampak terhadap pencemaran lingkungan dan keselamatan bisnis rumah sakit yang terkait dengan kelangsungan hidup rumah sakit. Salah satu tujuan penting dari penerapan sistem keselamatan pasien di rumah sakit adalah mencegah dan mengurangi Insiden Keselamatan Pasien (IKP) adalah suatu kejadian atau situasi yang dapat mengakibatkan atau berpotensi mengakibatkan cidera pada pasien. IKP meliputi kejadian yang tidak diharapkan (KTD), kejadian nyaris cidera (KNC), kejadian potensial cidera (KPC) dan kejadian cidera dalam proses asuhan pelayanan medis maupun asuhan pelayanan keperawatan dari yang ringan sampai yang berat. Keperawatan merupakan profesi yang berfokus kepada pelayanan dan bertujuan membantu pasien mencapai kesehatannya secara optimal. Oleh karena itu, pada saat memberikan asuhan keperawatan kepada pasien, perawat harus mampu memastikan bahwa pelayanan keperawatan yang diberikannya mengutamakan keselamatan pasien. Isu keselamatan pasien(patient safety) merupakan salah satu isu utama dalam pelayanan kesehatan. Patient safety merupakan sesuatu yang jauh lebih penting daripada sekedar efisiensi pelayanan. Perawat sebagai salah satu komponen utama pemberi layanan kesehatan, memiliki peran penting karena terkait langsung maupun tidak langsung sesuai dengan kemampuan yang dimilikinya. Perawat sebagai ujung tombak pelayanan kesehatan yang ada di lapangan sangat menentukan dalam upaya pencegahan dan pemutusan rantai transmisi infeksi dalam rangka memenuhi kebutuhan keamanan pasien . Perawat sebagai salah satu komponen sumber daya manusia (SDM) dalam sistem pelayanan kesehatan dirumah sakit, yang bertugas langsung pada garis depan dan mempunyai waktu lebih banyak berhadapan dengan pasien, tanpa mengabaikan peran tenaga kerja lainnya. Kinerja perawat dipengaruhi oleh 3 variabel yaitu variabel individu, variabel organisasi dan variabel psikologis. Dalam melakukan identifikasi pasien, perawat sudah melakukan identifikasi pasien dan memilah pasien, namun belum optimal dilaksanakan. Sedangkan dari segi komunikasi tampak efektif sesuai dengan standar JCI, ada komunikasi yang tepat, akurat dan efektif antara perawat, dokter dan pasien. Dalam pemberian obat-obatan sudah dilakukan sesuai dengan SOP di ruangan sesuai dengan JCI. Mutu pelayanan rumah sakit sebagian ditentukan juga oleh peran perawat.

Keselamatan pasien merupakan sesuatu yang jauh lebih penting dari pada sekedar efisiensi pelayanan, dan perilaku dengan kemampuan perawat sangat berperan penting. Salah 
satu peningkatan mutu pelayanan keselamatan pasien yaitu pencegahan dan pengurangan resiko infeksi dengan program yang diterapkan yaitu hand hygiene yang efektif. Keselamatan pasien rumah sakit adalah suatu sistem dimana rumah sakit membuat asuhan pasien lebih aman yang meliputi assesmen risiko, identifikasi, dan pengelolaan hal yang berhubungan dengan risiko pasien, pelaporan,dan analisis kejadian, kemampuan belajar dari kejadian dan tindak lanjutnya serta implementasi solusi untuk meminimalkan timbulnya risiko dan mencegah terjadinya cedera yang disebabkan oleh kesalahan akibat melaksanakan suatu tindakan atau tidak mengambil tindakan yang seharusnya diambil . Keselamatan pelayanan di rumah sakit salah satunya dimulai dari ketepatan identifikasi pasien. Karena salah identifikasi pasien diidentifikasi sebagai akar penyebab banyak kesalahan yang terjadi. Sasaran keselamatan pasien meliputi tercapainya halhal sebagai berikut:

$>$ ketepatan identifikasi pasien;

$>$ peningkatan komunikasi yang efektif;

$>$ peningkatan keamanan obat-obatan yang harus diwaspadai;

$>$ kepastian lokasi pembedahan yang benar, prosedur yang benar dan pembedahan pada pasien yang benar;

$>$ pengurangan risiko infeksi terkait pelayanan kesehatan;

$>$ pengurangan risiko cedera pasien akibat terjatuh.

Maksud dari sasaran keselamatan pasien adalah mendorong perbaikan spesifik dalam keselamatan pasien yang menyoroti bidang-bidang bermasalah dalam perawatan kesehatan, memberikan bukti dan solusi hasil konsensus yang berdasarkan nasihat para pakar. Perilaku perawat dengan kemampuan perawat sangat berperan penting dalam pelaksanaan keselamatan pasien. Perilaku yang tidak aman, lupa, kurangnya perhatian/motivasi, kecerobohan, tidak teliti dan kemampuan yang tidak memperdulikan dan menjaga keselamatan pasien berisiko untuk terjadinya kesalahan dan akan mengakibatkan cedera pada pasien. Perawat dalam memberikan asuhan keperawatan kepada pasien harus menerapkan keselamatan pasien. Perawat harus melibatkan kognitif, afektif, dan tindakan yang mengutamakan keselamatan pasien. Perawat dalam memberikan asuhan keperawatan harus penuh dengan kepedulian. Persepsi perawat untuk menjaga keselamatan pasien sangat berperan penting dalam pencegahan, pengendalian, dan peningkatan keselamatan pasien. 
Salah satu cara mencegah infeksi nasokomial adalah dengan mengeleminasi mikroba pathogen melalui tindakan aseptic, disinfeksi, dan strelisasi. Teknik dasar yang paling penting dalam mencegah dan penularan infeksi adalah dengan mencuci tangan. Lima partisipan juga menyebutkan lima waktu cuci tangan atau disebut dengan five moment, yaitu sebelum ke pasien, setelah dari pasien, setelah melakukan tindakan aseptic, setelah terkena cairan pasien, dan setelah dari lingkungan pasien. Selain itu, dua partisipan mengatakan hambatan untuk cuci tangan adalah lupa. Perawatan Rawat Inap adalah salah satu pelayanan kesehatan di rumah sakit yang dapat diakses oleh pasien yang membutuhkan perawatan intensif. Di rumah sakit ada berbagai macam obat, tes dan prosedur, peralatan, dan tenaga profesional dan non-profesional siap memberikan layanan. Keragaman dan keteraturan para pelayan jika tidak dikelola dengan baik dapat terjadi Keselamatan Pasien Insiden. Keselamatan pasien di rumah sakit melibatkan partisipasi dari semua petugas kesehatan, terutama perawat. Keselamatan pasien adalah prioritas utama dan harus segera dilaksanakan di rumah sakit karena dapat menyebabkan cedera langsung kepada pasien, terkait dengan kualitas dan nilai rumah sakit serta standar pelayanan yang harus dipenuhi oleh standar akreditasi rumah sakit.

\section{PENUTUP}

Keselamatan (safety) telah menjadi isu global untuk rumah sakit. Keselamatan pasien merupakan sesuatu yang jauh lebih penting dari pada sekedar efisiensi pelayanan, dan perilaku dengan kemampuan perawat sangat berperan penting. Salah satu sasaran keselamatan pasien adalah tercapainya pengurangan resiko infeksi terkait pelayanan kesehatan. Perawatan Rawat Inap adalah salah satu pelayanan kesehatan di rumah sakit yang dapat diakses oleh pasien yang membutuhkan perawatan intensif. Di rumah sakit ada berbagai macam obat, tes dan prosedur, peralatan, dan tenaga profesional dan non-profesional siap memberikan layanan. Perawat sebagai salah satu komponen sumber daya manusia (SDM) dalam sistem pelayanan kesehatan dirumah sakit, yang bertugas langsung pada garis depan dan mempunyai waktu lebih banyak berhadapan dengan pasien, tanpa mengabaikan peran tenaga kerja lainnya. Perawat dalam memberikan asuhan keperawatan kepada pasien harus menerapkan keselamatan pasien. Perawat harus melibatkan kognitif, afektif, dan tindakan yang mengutamakan keselamatan pasien. Persepsi perawat untuk menjaga keselamatan pasien sangat berperan penting dalam pencegahan, 
pengendalian, dan peningkatan keselamatan pasien. Salah satu cara mencegah infeksi nasokomial adalah dengan mengeleminasi mikroba pathogen melalui tindakan aseptic, disinfeksi, dan strelisasi. Teknik dasar yang paling penting dalam mencegah dan penularan infeksi adalah dengan mencuci tangan.

\section{DAFTAR PUSTAKA}

Bawella, S. C., dkk. (2013, Agustus). Hubungan Pengetahuan dan Sikap Perawat dengan Pelaksanaan Keselamatan Pasien (Patient Safety) di Ruang Rawat Inap RSUD linn Kendage Tahuna. E-journal Keperawatan, Vol. 1, No. 1.

Fetnaningsih, D., dkk. (2016, Maret). Beban Kerja Perawat Terhadap Implementasi Patient Safety di Ruang Rawat Inap. Jurnal Keperawatan Soedirman (The Soedirman Journal Of Nursing), Vol. 11, No. 1.

Herawati, Tri Yennike. (2015 Maret). Budaya Keselamatan Pasien Di Ruang Rawat Inap Rumah Sakit X Kabupaten Jember. Jurnal IKESMA, Vol.11, No. 1.

Isnaini, N. M. \& Rofii, M. (2014, Mei). Pengalaman Perawat Pelaksana dalam Menerapkan Keselamatan Pasien. Jurnal Managemen Keperawatan, Vol. 2, No. 1. Hal. 31.

Ismainar, H. (2019). Keselamatan Pasien di Rumah Sakit. Yogyakarta: Deepublish.

Kartika, I. R., dkk. (2019 Juni). Deskripsi Penerapan Patient Safety Pada Pasien Di Bangsal Bedah. Jurnal Human Care. Vol.4, No. 2. Hal. 86-94.

Lombogia, A., dkk. (2016, Juli). Hubungan Perilaku dengan Kemampuan Perawat dalam Melaksanakan Keselamatan Pasien (Patient Safety) di Ruang Akut Instalasi Gawat Darurat RSUP Prof. DR. R. D. Kandou Manado. E-journal Keparawatan (e-Kp), Vol. 4, No. 2, Hal. 2-5.

Neri, R. A., dkk. (2018, Juli). Analisis Pelaksanaan Sasaran Keselamatan Pasien di Rawat Inap Rumah Sakit Umum Daerah Padang Pariaman. Jurnal Kesehatan Andalas.

Pujilestari, A., dkk. (2014, Maret). Budaya Keselamatan Pasien di Instalasi Rawat Ibap RSUP DR. Wahidin Sudirohusodo Kota Makasar. Jurnal MKMI, Hal. 57-64. 
Setiyani, M. D., dkk. (2016, Januari). Implementasi Sasaran Keselamatan Pasien di Ruang Rawat Inap RSU Kabupaten Tanggerang. JKFT, Edisi No. 2.

Simamora, R.H., \& Nurmaini, C.T.S. (2019). Knowledge of Nurses About Prevention of Patient Fall Risk in Inpatient Room of Private Hospital in Medan. Indian Journal of Public Health Research \& Development, 10 (10), 759-763.

Yusuf, Muhammad. (2017). Penerapan Patient Safety Di Ruang Rawat Inap Rumah Sakit Umum Daerah Dr. Zainoel Abidin. Jurnal Ilmu Keperawatan, 5:1. 